\title{
PREDICTION OF ELASTIC PROPERTIES OF POLYURETHANE-INFILTRATED CARBON FOAMS
}

\begin{abstract}
SUMMARY
This paper presents micromechanical approach to assessment of elastic properties of composite polyurethane-carbon foams. Analysis is based on specific choice of RVE combined with micro-macro transition. It leads to evaluation of strength and elastic constants of a composite. Foam behaviour is investigated numerically. Solid skeleton part shape is based on the tetrahedron cut out with spheres. $3 D$ unit cell model is FE discetized. Calculations are performed for foams of selected densities using ABAQUS system. The comparison shows good agreement between the theoretical approach and experimental data. The presented method may be applied to design novel materials such as graphitized foam and nano composites and tailoring these materials for desired elastic properties.
\end{abstract}

Keywords: composites, micromechanics, mechanical properties, polyurethane-infiltrated carbon foams

\section{NUMERYCZNE OSZACOWANIE WEASNOŚCI SPREŻYSTYCH KOMPOZYTOWYCH PIAN WĘGLOWO-POLIURETANOWYCH}

\begin{abstract}
Artykut przedstawia zastosowanie podejścia mikromechanicznego do oszacowania własności sprężystych kompozytowych pian poliuretanowo-węglowych. Analiza ośrodka sprężystego jest oparta na podejściu mikromechanicznym, które prowadzi do określenia własności sprężystych kontinuum, jakim jest materiat kompozytowy na podstawie reprezentatywnej komórki. Ksztalt szkieletu komórki jest oparty na czworościanie z wyciętymi sferami wypetnionymi innym materiatem. Obliczenia sa przeprowadzone programem ABAQUS metoda elementów skończonych. Porównanie wyników numerycznych i eksperymentalnych dla wybranych gęstości pian wskazuje na duża zgodność przewidywań teoretycznych z eksperymentem. Przedstawiona metoda może być użyta do projektowania pian kompozytowych o z góry zadanych własnościach sprężystych.
\end{abstract}

Slowa kluczowe: modelowanie mikromechaniczne, własności sprężyste, poliuretanowo-węglowe piany kompozytowe

\section{INTRODUCTION}

Carbon foams reveal unique mechanical and thermal properties, which make them an attractive material for energy absorbing or insulating structural components in advanced aircraft structures. In recent years carbon-based composites are made to achieve an advantageous combination of properties. The examples are: nanofiber reinforced carbon foam, graphitized carbon foam or foams infiltrated by polymers, metals or ceramic carbon. These materials are designed to achieve high strength. Generally, such composites reveal improved mechanical properties. Examples of such a composite, including the experimental results for infiltrated polyurethane carbon foams of various densities are described by Bunning (2003). He reports that tensile strength and Young modulus may increase tenfold for the composites compared to unfilled foam.

Production process, involving a continuous liquid phase that solidifies, and precursor type determine morphology of the foam. Films of liquid phase meet at equal angles of $120^{\circ}$ and form a film junction called Plateau border (Fig. 1). Four plateau borders join at the tetrahedral angle of $109.47^{\circ}$. For open cell foams they are identified as foam ligaments.

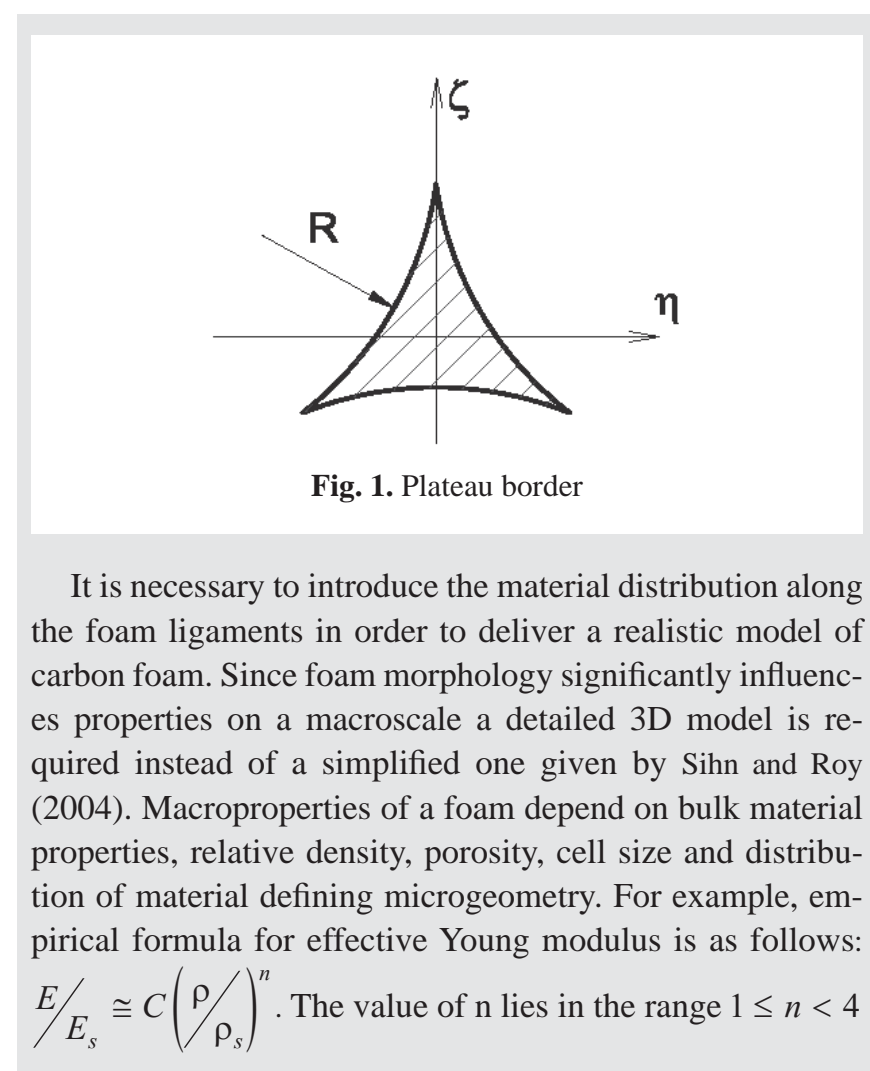

\footnotetext{
* Institute of Structural Mechanics, Department of Civil Engineering Cracow University of Technology Cracow, Poland mjm@limba.wil.pk.edu.pl
} 
yielding a wide range of properties at a given density and depends only on the material distribution in the skeleton structure.

The best known approach for investigating materials exhibiting repetitive periodic structure is based on micromechanics and is connected with the proper choice of a representative unit cell (Nemat-Nasser and Hori 1999).

A number of micromechanical models are known in the literature. The first one, based on a tetrahedral element, was adopted by Warren and Kraynik (1988); the representative tetrahedral element consists of four identical half struts meeting at equal tetrahedral angles. This choice of a microstructural element is consistent with the topological feature of foam presented previously. The relative orientation of adjacent tetrahedral elements having a common strut is assumed to be random. The boundaries of the unit cell consist of four planes perpendicular to each strut at its midpoint and form a regular tetrahedron. This model enables us to obtain only averaged elastic constants over all possible orientations and to estimate the elastic properties of the foam. The similar idea of creating representative unit cell is presented by Janus-Michalska (2003) but for foams of low density using beam model of skeleton. Important fact is that choosen RVE exhibits material symmetry typical for isotropy. This reduces averaging in direction and simplifies solution.

Kelvin model based on partitioning space into identical tetrakaidecahedral cells of equal volume and minimal surface area is also used. This model is referred to as Kelvin foam and was adopted by Zhu et al. (1997) as well as Warren and Kraynik (1987).

Representative volume element is repeated to represent the entire foam structure. Real cellular structures are random. In order to describe foams sensitive to random unit cell dimensions Voronoi tesselation technique is used as described by Roberts and Garboczi (2002). Alternatively computational modeling based on CAD may be applied, where finite element discrestization is derived from real foam specimen by computer tomography.

Sihn and Roy (2004) proposed a 3D model of unit cell for carbon foam taking into account real distribution of carbon in skeleton structure. Foam forming process is simulated with expansion of four bubles, centred in four vertices of tetrahedron yielding skeleton of the unit cell of a foam. (Fig. 2)

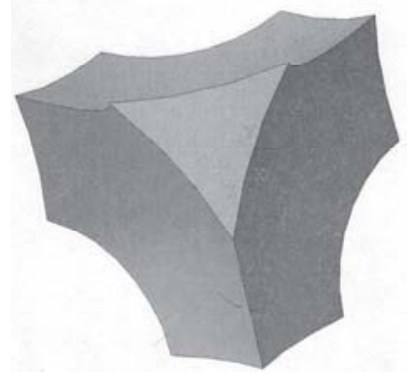

Fig. 2. Representative volume element of skeleton typical for carbon foams
This work presents an anapplication of the micromechanical approach to composite carbon-polyurethane foam. The results are obtained using FEM applied to a unit cell in order to evaluate elastic constants and strength of the composite. The examples are choosen so, that they can be compared with the experimental ones given by Bunning (2003).

\section{MICROMECHICAL ANALYSIS}

Micromechanical approaches have been widely developed to assess the mechanical behaviour of the foams (Janus-Michalska 2003, Menges and Kipschild 1975, Warren and Kraynik, 1987, 1988, Zhu et al. 1997).

The overall effective properties are determined by considerations using a micro-macro transition. The effective properties are then used to determine the response of structural elements on a macro scale. Such an approach is typical for micromechanics. The bases of the micromechanical algorithm is given by Nemat- Nasser and Hori (1999).

\subsection{Representative volume element}

A typical algorithm begins with choosing RVE. Unit cells fill the space by repetition without gaps or overlaps. No cell in a three-dimensional foam is a simple polyhedron. Tetrahedra do not fill out the space so our geometric assumptions are not exactly compatible with any three-dimensional network. Although the results cannot be exact they provide useful insight into foam mechanics. RVE modeling of foam, given below, does not fulfill this requirement, although it is used by many authors (Warren and Kraynik 1987, 1988, 1997, Zhu et al. 1997).

The data of cell geometry shown in Figure 3 is given below:

Points coordinates:

$\begin{array}{llll}1(-a, a, a) & 2(-a,-a, a) & 3(a,-a, a) & 4(a, a, a) \\ 5(-a, a,-a) & 6(-a,-a, a) & 7(-a, a,-a) & 8(a, a,-a)\end{array}$

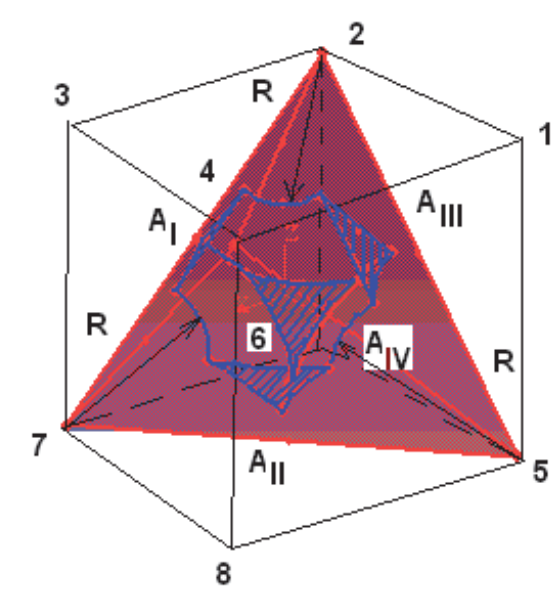

Fig. 3. Representative volume element of carbon polyurethane composite foam 
Four spheres centered on points $2,5,6,7$ with radii sati-sfying condition $\sqrt{2} a \leq R \leq \frac{2 \sqrt{6}}{3} a$ cut out solid skeleton with four cell boundary faces $A_{I}, I=\mathrm{I}, \mathrm{II}, \ldots, \mathrm{IV}$ (Sihn and Roy 2004).

Unit normals to cell boundary are:

$$
\begin{aligned}
& \mathbf{n}_{I}=(1 / \sqrt{3},-1 / \sqrt{3}, 1 / \sqrt{3}) \\
& \mathbf{n}_{I I}=(1 / \sqrt{3}, 1 / \sqrt{3},-1 / \sqrt{3}) \\
& \mathbf{n}_{I I I}=(-1 / \sqrt{3}, 1 / \sqrt{3}, 1 / \sqrt{3}) \\
& \mathbf{n}_{I V}=(1 / \sqrt{3}, 1 / \sqrt{3}, 1 / \sqrt{3})
\end{aligned}
$$

$R / a$ ratio determines porosity of foam $\varphi$ defined as follows: $\varphi=1-V_{s} / V$

where:

$$
V=8 a^{3} / 3 \text { - tetrahedron volume. }
$$

A representative volume element for composite foam is given in Figure 3. Carbon skeleton (Fig. 2) is made of carbon, empty space is filled with polyuerthane.

\subsection{Stiffness matrices}

The framework of micromechanical analysis starts with loading RVE with boundary displacements giving uniform strain state as follows:

$$
\boldsymbol{\varepsilon}=\left\langle\boldsymbol{\varepsilon}^{s}\right\rangle_{V}=\frac{1}{V} \sum_{A_{I}} \operatorname{sym}\left(\mathbf{n}_{i} \otimes \mathbf{u}_{i}\right) d A
$$

where:

$\mathbf{u}_{i}$ - displacement vector for points on $A_{I}$ plane,

$\mathbf{n}_{i}-$ unit normal to the cell boundary $A_{I}$.

The following strain states are considered:

1. uniaxial strain $\varepsilon_{x} \neq 0, \varepsilon_{y}=\varepsilon_{z}=0$,

2. shearing $\gamma_{x y}=\gamma_{y z}=\gamma_{x z}$,

3. triaxial strain $\varepsilon_{x}=\varepsilon_{y}=\varepsilon_{z}$.

Next the resultant surface tractions normal and tangent to $A_{I}$ faces

$$
\begin{aligned}
& { }^{K} p_{I n}=p_{I n}\left({ }^{K} \varepsilon\right),{ }^{K} p_{I \tau}=p_{I \tau}\left({ }^{K} \varepsilon\right) \quad I=\mathrm{I}, \mathrm{II}, \ldots, \mathrm{IV} \\
& K=1,2,3
\end{aligned}
$$

in skeleton are obtained.

The way of calculating the effective stress tensor components.

Cutting through the representative volume element with plane $\pi: x=0$ as shown in Figure 4, one splits unit cell in two, thus yielding face $A_{I, X}{ }^{-}, A_{I, X}{ }^{+} . I=\mathrm{I}, \mathrm{II}, \ldots, \mathrm{IV}$. Con- sidering the effective stress that has to act upon the exposed face to maintain the equilibrium with tractions on the remaining faces one obtains the following equilibrium equation:

$$
\begin{aligned}
& A_{x}\left(\sigma_{x x} \vec{e}_{x}+\sigma_{x y} \vec{e}_{y}+\sigma_{x z} \vec{e}_{z}\right)+\vec{p}_{1} A_{I, x}{ }^{-}+\vec{p}_{2} A_{I I, x}{ }^{-}+ \\
& +\vec{p}_{3} A_{I I I, x}{ }^{-}+\vec{p}_{4} A_{I V, x}{ }^{-}=0
\end{aligned}
$$

cutting plane $\pi: y=0$, yields faces: $A_{I, Y}{ }^{-}, A_{I, Y}{ }^{+} I=\mathrm{I}, \mathrm{II}, \ldots, \mathrm{IV}$, and this results in equation:

$$
\begin{aligned}
& A_{y}\left(\sigma_{y x} \vec{e}_{x}+\sigma_{y y} \vec{e}_{y}+\sigma_{y z} \vec{e}_{z}\right)+\vec{p}_{1} A_{I Y}{ }^{-}+\vec{p}_{2} A_{I Y}{ }^{-}+ \\
& +\vec{p}_{3} A_{I Y}{ }^{-}+\vec{p}_{4} A_{I Y}{ }^{-}=0
\end{aligned}
$$

cutting plane $\pi: z=0$ yields faces $A_{I, Z}{ }^{-}, A_{I, Z}{ }^{+}, I=\mathrm{I}, \mathrm{II}, \ldots, \mathrm{IV}$ and equations:

$$
\begin{aligned}
& A_{z}\left(\sigma_{z x} \vec{e}_{x}+\sigma_{z y} \vec{e}_{y}+\sigma_{z z} \vec{e}_{z}\right)+\vec{p}_{1} A_{I, Z}{ }^{-}+\vec{p}_{2} A_{I I, Z}{ }^{-}+ \\
& +\vec{p}_{3} A_{I I I, Z}{ }^{-}+\vec{p}_{4} A_{I V}{ }^{-}=0
\end{aligned}
$$

where $A_{x}=A_{y}=A_{z}=A=\frac{a^{2}}{2}$ are the square sections and $\vec{e}_{x}, \vec{e}_{y}, \vec{e}_{z}$ are the unit vectors associated with global coordinate system. The solution of this set of equations yields stress tensor components.

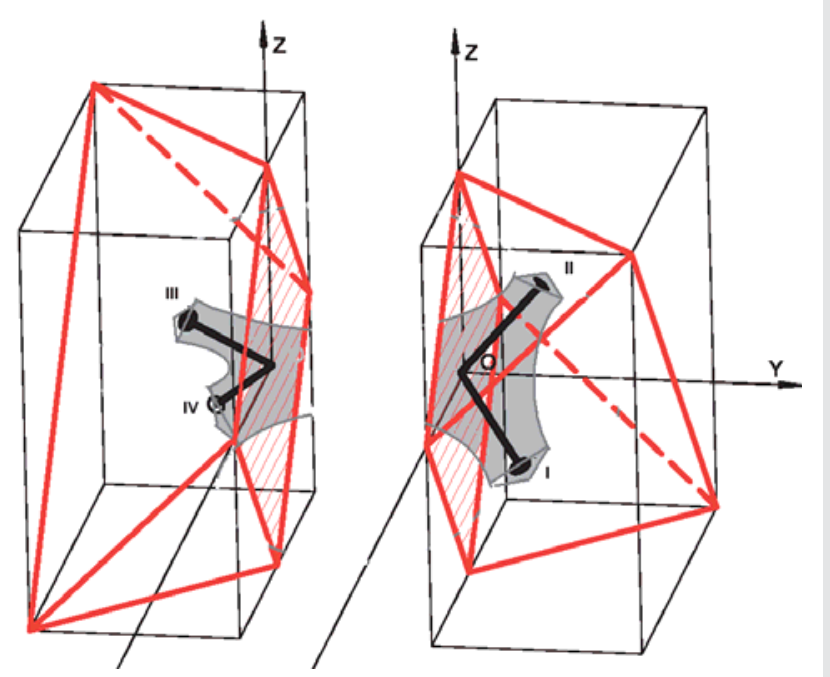

Fig. 4. Plane for calculating effective stress vector

On the basis of the previous analysis an effective constitutive matrix for the unit cell is constructed.

Representative volume element exhibits cubic symmetry (Warren and Kraynik A.M. 1997) represented by the following stiffness matrix:

$$
\underline{\mathbf{S}}=\left[\begin{array}{cccccc}
s_{1111} & s_{1122} & s_{1122} & 0 & 0 & 0 \\
s_{1122} & s_{1111} & s_{1122} & 0 & 0 & 0 \\
s_{1122} & s_{1122} & s_{1111} & 0 & 0 & 0 \\
0 & 0 & 0 & 2 s_{1212} & 0 & 0 \\
0 & 0 & 0 & 0 & 2 s_{1212} & 0 \\
0 & 0 & 0 & 0 & 0 & 2 s_{1212}
\end{array}\right]
$$


(axes $x, y, z$ are correspond to indices $1,2,3$ respectively):

Three independent elastic constants are expected in cubic symmetry: bulk modulus of the form $K=\frac{1}{3}\left(s_{1111}+2 s_{1212}\right)$ and two shear moduli $\mu_{1}=\frac{1}{2}\left(s_{1111}-s_{1212}\right), \mu_{2}=s_{1212}$.

Cubic symmetry may be described by defining a degree of anisotropy $J=\frac{\mu_{1}}{\mu_{2}}$.

The representative element exhibits an additional axes of symmetry. Every axis perpendicular to the cell face pointing towards $I=\mathrm{I}, \mathrm{II}, \mathrm{II}, \mathrm{IV}$ is the axis of planar isotropy since Plateau border is isotropic in its plane (triple axis of symmetry results in isotropy). An additional axis of symmetry changes the symmetry from cubic to isotropic. For isotropy $J=1$.

As a material on macroscale foam is isotropic. Isotropic RVE means that the orientation of a cell may be arbitrary. The macroscopic moduli for foam are identical with moduli of a representative unit cell. In the case of two material constants it is necessary to consider only two of the strain states listed in 2.2

\section{NUMERICAL RESULTS}

Two types of composite foams are considered, using data specified in Table 1. Component material data are as follows:

$\begin{array}{ll}\text { Polyurethane data: } & \\ \text { tensile modulus } & -1700 \mathrm{MPa}, \\ \text { compressive modulus } & -750 \mathrm{MPa}, \\ \text { tensile strength } & -35 \mathrm{MPa}, \\ \text { compressive strength } & -40 \mathrm{MPa} . \\ \rho_{P U}=1.1 \mathrm{~g} / \mathrm{cm}^{3} . & \end{array}$

Carbon data:

tensile modulus $\quad-6.79 \mathrm{GPa}$, compressive modulus $-6.79 \mathrm{GPa}$, $v_{s}=0.33$, $\rho_{C}=1.4 \mathrm{~g} / \mathrm{cm}^{3}$.

Table 1

Specification of carbon skeleton

\begin{tabular}{|c|c|c|c|}
\hline Type of foam & $\begin{array}{c}a \\
{[\mathrm{~mm}]}\end{array}$ & $\begin{array}{c}R \\
{[\mathrm{~mm}]}\end{array}$ & $\begin{array}{c}\text { Porosity } \\
{[\%]}\end{array}$ \\
\hline I & 1.276 & 1.875 & 92 \\
\hline II & 1.080 & 1.435 & 86 \\
\hline
\end{tabular}

The finite element analysis was performed using the ABAQUS system. 10-node tetrahedral tetrahedron elements with second order approximation (C3D10M) have been used to discretize skeleton structure. A surface-based tie constraint, which ties two surfaces together for the duration of a simulation modeled interfacial interaction. Calculations have been performed for discretization of RVE by 1024 elements for each of constituent material. (A comparison with results for 128 elements gives the relative error of these two solutions $e=2.8 \%$ ).

Table 2

Tensile modulus $E$ [MPa]

Comparison of the experimental results with results predicted using presented model and other models available in literature (Bunning et al., 2003)

\begin{tabular}{|c|c|c|c|c|}
\hline $\begin{array}{c}\text { Type } \\
\text { of foam }\end{array}$ & $\begin{array}{c}\text { Experi- } \\
\text { ment }\end{array}$ & $\begin{array}{c}\text { Presented } \\
\text { model }\end{array}$ & $\begin{array}{c}1 \text { series } \\
\text { model }\end{array}$ & $\begin{array}{c}2 \text { paralell } \\
\text { model }\end{array}$ \\
\hline I & 4400 & 5340 & 1900 & 2400 \\
\hline II & 4000 & 4980 & 1950 & 2500 \\
\hline
\end{tabular}

Numerical results also confirm isotropy.

\section{CONCLUSIONS}

The micromechanical model is applied to carbon and polyurethan composite foams. The elastic behaviour of open-cell foam is investigated numerically on the basis of the analysis of a representative volume element. A solid carbon skeleton part is based on the shape of tetrahedron cut out with three spheres. Cut out spaces of tetrahedron are filled with polyurethane. The 3D unit cell model is discetized by FE. Calculations were performed using ABAQUS system. By applying appropriate spatial boundary displacements various multiaxial strain states are created in the foam. Elastic constants for foam treated as isotropic equivalent continuum are obtained as the results of the numerical calculations. Two loading cases: hydrostatic tension and pure shear are sufficient to estimate material constants for foam treated as isotropic material.

Improved elastic properties of carbon foam, especially the higher value of Young modulus E, are related to the improved foam infiltration ability by polyurethane.

An analysis was carried out for foams with two different relative densities. Numerical results obtained by ABAQUS show good agreement with the experimental results. The presented model is better than series and parallel models known in the literature.

Interfacial bonding properties defining the contact of two materials may significantly influence the scale of the mechanical reinforcement. A comparison with real results given by experiment shows that in this type of composite, faces of two materials are nearly tied, which gives advantageous reinforcement. In other cases of interfacial interaction we need information about microstructural properties of constituent materials and interfacial contact should be modeled by the use of cohesive elements. 
The presented method may be applied to novel materials such as graphitized foam and nano composites.

\section{References}

Beechem T., Lafdi K. 2006, Novel high strength graphitic foams, Carbon, 44 , pp. $1548-1559$.

Bunning T., Jeon H., Roy A., Kearns K., Farmer B., Adams W. 2003, Polyurethane infiltrated carbon foams: a coupling of thermal and mechanical properties, Journal of Applied Polymer Science.

Chong C., Kennel E., Stiller A., Stansberry P., Zondlo J. 2006, Carbon foam derived from various precursors, Carbon, 44, pp. 1535-1543.

Gibson L.J., Ashby M.F. 1982, The mechanics of three-dimensional cellular materials, Proc. Roy. Soc. Lond., A382, pp. 43-59.

Gibson L.J., Ashby M.F. 1998, Cellular Solids, 2nd ed., Cambridge University Press.

Janus-Michalska M., Pęcherski R. 2003, Macroscopic Properties of OpenCell Foams Based on Micromechanical Modelling, Technische Mechanik, Band 23, Heft 2-4, pp. 234-244.

Kirca M., Gul A., Ekinci E., Yardim F., Mugan A. 2007, Computational modeling of micro-cellular carbon foams, Finite Elements in Analysis and Design, 44, pp. 45-52.

Mehrabadi M.M., Cowin C. 1990, Eigentensors of linear anisotropic elastic materials, Q. Journal Mech. Appl. Math., 43, pp. 15-41.
Mehta R., Anderson D., Hager J. 2003, Graphitic open-celled carbon foams: processing and characterization, Carbon, 41, pp. 2159-2179.

Menges G., Kipschild F. 1975, Estimation of mechanical properties for rigid polyurethane foams, Polymer Eng. Sci., 15, pp. 623-627.

Nemat-Nasser S., Hori M. 1999, Micromechanics, 2nd ed., Elsevier.

Roberts A.P., Garboczi E.J. 2002, Elastic properties of model random threedimensional open-cell solids, J. Mech. Phys. Solids, 50, pp. 33-53.

Rychlewski J. 1995, Unconventional approach to linear elasticity, Arch. Mech., 47, pp. 149-171.

Sihn S., Roy A.K. 2004, Modeling and prediction of bulk properties of open-cell carbon foam, Journal of the Mechanics and Physics of Solids, 52, pp.167-191.

Wang Y., Cuitiño A.M. 2000, Three-dimensional nonlinear open-cell foams with large deformations, J. Mech. Phys. Solids, 48, pp. 961-988.

Warren W.E., Kraynik A.M. 1987, Foam mechanics: the linear elastic response of two-dimensional spatially periodic cellular materials, Mechanics of Materials, 6, pp. 27-37.

Warren W.E., Kraynik A.M. 1988, The Linear Elastic Properties of OpenCell Foams, J. Appl. Mech., 55, pp. 341-346.

Warren W.E., Kraynik A.M., 1997, Linear Elastic Behavior of a Low-Density Kelvin Foam with Open Cells, J. Appl. Mech., vol. 64, pp.787-794.

Wicklein M., Thoma K. 2005, Numerical investigations of the elastic and plastic behaviour of an open-cell aluminum foam, Materials Science and Engineering A, 397, pp. 391-399.

Zhu H.X., Knott J.F., Mills N.J. 1997, Analysis of the Elastic Properties of Open-Cell Foams with Tetrakaidecahedral Cells J. Mech. Phys. Solids, 45, pp. 319-343. 